\title{
Determinant of IHSG Index; Indonesia Stock Exchange
}

\author{
Nazir $^{1}$, Marzuki ${ }^{1}$, M. Subhan ${ }^{1}$, Fajria Ananda ${ }^{1}$, Husaini $^{1}$, Wahyuddin Albra ${ }^{1}$, Apridar \\ Abdurrahman ${ }^{1}$ and Hamdani ${ }^{2}$ \\ \{nazir-palohbatee@yahoo.com\} \\ ${ }^{1}$ Departement of Management, Universitas Malikussaleh, Aceh, Indonesia \\ ${ }^{2}$ Department of Business Administration Studies Banking Finance, Politeknik Negeri Lhokseumawe, \\ Aceh, Indonesia
}

\begin{abstract}
Stock is a scurity that indicates a share of ownership of a bussiness entity. The change in the movement of the share price index indefinitely influences the global share price index. Stock price movement in the market as a whole are seen in the index of joint stock prices which is an index used in measuring the formance of shares traded on a stock exchange. This study aims to analyze the determination of Indonesia Composite Stock Price Index (IHSG). Secondary data used in this study at 30 companes from 2013-2015. Sample selection used is purposive sampling method. Data was analized using multiple regressions. The result of the research founded Nasdaq index, Dow Jones index and Strait Times index significantly influence to Composite Stock Price Index at Indonesia Stock exchange (IHSG). The result becomes a reference for investors to predict the movement of IHSG in Indonesia. The fluctuation of stock price on the stock exchange within a country is determined by the stock price of other countries and this phenomenon is called contagion effect.
\end{abstract}

Keywords: Nasdaq, Dow Jones, Strait Times and IHSG indexes

\section{Introduction}

Stock is a security that indicates a share of ownership of a business entity. In carrying out the business the investors will get dividend based on the number of shares held by each of them. Shares can be classified into two categories; common stock and preferred stock. Common stock represents ownership claims on the income and assets owned by the company. Furthermore, preferred stock is ownership has more rights than the common stock ownership. Preferred shareholders will be claimed first and also have more voting rights than the rights of common stockholders.

In Indonesia Stock Exchange are many types of indexes; Sectoral index, LG45 index, IHSG index, Sharia index, Kompas100 index and Main board index and individual index. Stock indexes is a historical information related to the movement of the composite stock price at a certain time and reflects a value that serves as a measure of the performance of joint stocks in the stock exchange [1]. All of stock price indexes become the indicators of market trends either active or sluggish. The active market is a market situation that reflects the rising 
prices of securities and commodities at a given time, while the sluggish market is a market situation that reflects lower the price of securities at any given moment.

In Indonesia Stock Exchange are many types of indexes; Sectoral index, LG45 index, IHSG index, Sharia index, Kompas100 index and Main board index and individual index. Stock indexes is a historical information related to the movement of the composite stock price at a certain time and reflects a value that serves as a measure of the performance of joint stocks in the stock exchange [1]. All of stock price indexes become the indicators of market trends either active or sluggish. The active market is a market situation that reflects the rising prices of securities and commodities at a given time, while the sluggish market is a market situation that reflects lower the price of securities at any given moment.

\section{Literature Review}

\subsection{Capital Market}

The capital market is a place of transactions for buying and selling of financial instruments such as stocks and bonds. Capital market acts as an intermediary in supporting the economy of a country. Capital market can connect between people who have excess funds with people who have lack of funds. In the decree of the Minister of Finance of the Republic of Indonesia Number 1548 of 1990 mentioned capital market shaped place in the form of a building to sell securities by using an intermediary. The notion of the capital market is broadly related to intermediates such as banking in the commercial and other financial intermediaries. While the capital market in the middle sense relates to institutions that sell and sell financial instruments are long term [2].

Capital market is a market related to equity and debt [3]. The capital market is divided into the primary and secondary market. The primary market is entity that issued securities market, while the secondary market is trading of securities between investors after sold by first buyer. The capital market plays a role in mediating between investors and companies in the framework of supply and demand for long-term financial instruments. Types of financial instruments consist of warrant, rights issue, common stock, preferred stock, bonds and convertible bonds [4]. Nowadays all countries have a capital market to grow their country's economy, and place invest by their citizens in order to improve their welfare.

\subsection{The Stock Price Index}

The movement of the stock price index can signal the growth of investment in a country, and the movement is certainly there are factors that affect, among others the domestic factor itself such as inflation rate, interest rate, exchange rate and other macroeconomic in addition is also influenced by such as the Nasdaq index, the Dow Jones index, the Straits Times index, and other global indices. Overall market performance will be seen in the Composite Stock Price Index and can be used as parameters of the economy rate of a country. Composite Stock Price Index is the overall stock price movement as a reference of trend development in capital market [5].

In the IHSG Index, all types of stocks listed on the stock exchange have fluctuation in any time either per minute, hourly and daily due to market price changes and an increase in the number of shares. The IHSG Index can also be used as an indicator of securities trading reflecting stock volatility [6]. One country's stock price index is always integrated with other 
country's stock price indexes, especially the global stock price index, as evidenced by the Darrat and Zhong [7] study that found US and Japanese stock markets affected the Asia Pacific stock market.

\section{Method}

The population in this study is all companies incorporated in IHSG Index, and foreign index; Nasdaq index, Dow Jones index and Straits Times index The sample is each index as many as 30 companies. Sample selection technique used purposive sampling. The sample obtained since 2014 to 2015 and analyzed by using multiple regression with formula:

$$
\mathrm{IHSG}=\alpha+\beta_{1} N I+\beta_{2} D I+\beta_{3} I S+\mathrm{e} .
$$

IHSG : Indonesian Composite of Stock Price Index
NI : Nasdaq Index
DI : Dow Jones Index
IS : Straits Time Index

\section{Result}

\subsection{Normality Test}

The data normality test is used to test whether the residual data in the regression on independent and dependent variables is normally distributed. The results of normality test the data is normal and can be seen on the probability plot figure 1 below.

\section{Normal P-P Plot of Regression Standardized}

Residual

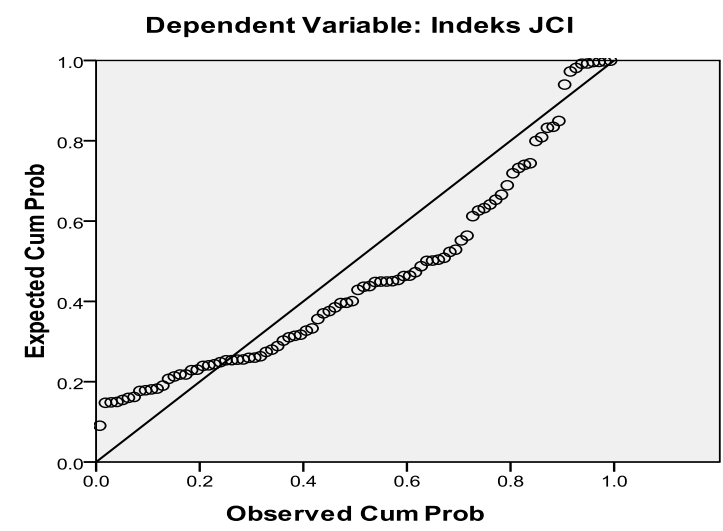

Fig. 1 Normality test probability plot 


\subsection{Autocorrelation Test}

The autocorrelation test is used to determine the relationship between intrusion errors that arise in time series data. The results of the autocorrelation test found the number of DW is 2.226, between dl 1.5889 and du 1.7264. Based on this concluded the data is no indicated autocorrelation can be seen in table 1 below.

Table 1. Autocorrelation Test

\begin{tabular}{rrr}
\hline \multicolumn{3}{c}{ Model Summary $^{\mathrm{b}}$} \\
\hline & $\begin{array}{c}\text { Std. Error of the } \\
\text { Estimate }\end{array}$ & $\begin{array}{c}\text { Durbin- } \\
\text { Watson }\end{array}$ \\
\hline 1 & 15.22917 & 2.226 \\
\hline
\end{tabular}

\subsection{Multicollinearity Test}

The multicollinearity test is to know the correlation between the independent variables. The result of the statistic test found that all of variables are unimpeded of multicolliearity because the value of Tolerance is greater than 0.1 and the value of VIF is less than 10 , as show as in table 2 .

Table 2. Multicolinearity Test

\begin{tabular}{lcr}
\hline \multicolumn{1}{c}{ Model } & \multicolumn{2}{c}{ Collinearity Statistics } \\
\hline & Tolerance & \multicolumn{1}{c}{ VIF } \\
\hline (Constant) & & \\
Nasdaq Index & .975 & 1.026 \\
Dow Jones Index & .944 & 1.059 \\
Strait Times Index & .966 & 1.035 \\
\hline
\end{tabular}

\subsection{Heteroscedasticity Test}

This test is performed to see in the regression model whether there is variance inequality from residual one observation to others. Heteroscedasticity test result found that the data is homoscedasticity because the posit spreands both above and below Y. For the specific can be seen in the figure 2. 


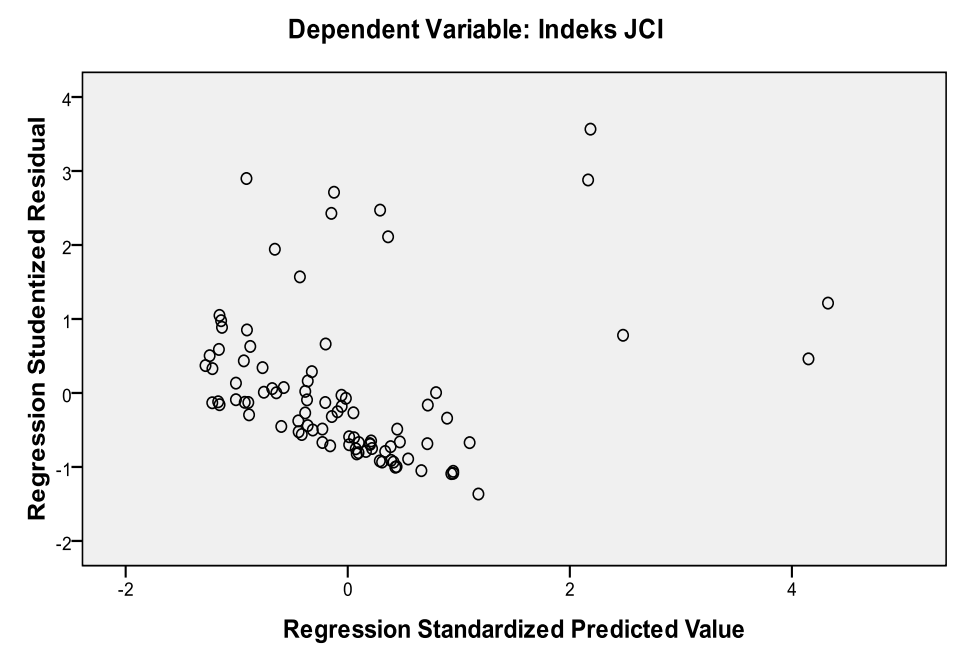

Fig. 2 Heteroscedasticity test scatter plot

\subsection{Correlation Coefficient Analysis and Coefficient of Determination}

Correlation coefficient is useful to know the relationship between independent variables to the dependent variable. Then the coefficient of determination to see how much variation of independent variables to the dependent variable. The results of correlation coefficient and determination can be seen in table 3 below.

Table 3. Coefficient Correlation

\begin{tabular}{cccr}
\hline \multicolumn{4}{c}{ Model Summary $^{\mathrm{b}}$} \\
\hline Model & R & R Square Adjusted R Square Std. Error of the Estimate \\
\hline $10.477^{\mathrm{a}}$ & 0.277 & 0.200 & 15.22917 \\
\hline
\end{tabular}

Based on the table above the coefficient correlation $(\mathrm{R})$ is 0.477 . It means the Nasdaq index, Dow Jones index and Straits Times index corresponds to the IHSG Index of $47.7 \%$. The value of $\mathrm{R}^{2}$ is 0.277 , this shows the variation of Nasdaq index, Dow Jones index and Straits Times index able to explain its influence to the IHSG Index of $27.7 \%$, remain the $72.3 \%$, influenced by other variables.

\subsection{Determinant of IHSG Index}

In this table show the factors that determine of IHSG Index in Indonesia Stock Exchange use partially statistic test. Based on statistic test show that significance value of independent variables are less than $5 \%(0.05)$. Then the value $t_{\text {statistic }}$ is greater that $t_{\text {table. }}$. It means the whole of independent variables have a positive impact on the dependent variable. For specific view can be seen in table 4 below. 
Table 4. Partially Test

\begin{tabular}{llrrrr}
\hline \multicolumn{1}{c}{ Model } & \multicolumn{1}{c}{ Coefficients $^{\mathrm{a}}$} & & & \\
\hline 1 & (Constant) & -7.500 & $\mathrm{t}_{\text {Statistic }}$ & $\mathrm{t}_{\text {table }}$ & \multicolumn{1}{c}{ Sig. } \\
\hline & Nasdaq Index & 9.904 & 4.174 & .108 \\
& Dow Jones Index & 10.069 & 3.007 & 1,662 & .000 \\
Straits Times Index & 4.067 & 2.067 & & .003 \\
\hline
\end{tabular}

\section{Discussion}

The fluctuation of stock price on the stock exchange in a country is determined by the stock price of other state exchanges, it is related to economic factor, technological sophistication and communication as well as due to investor uniformity Achsani [8]. This is evident from the results of this study that IHSG is influenced by Nasdaq index in the United States. This shows the rise in the Nasdaq index in the United States followed by the rise in the price index of IHSG in Indonesia. This event is called a contagion effect which means that if the stock price index of a country is changed it will be followed by other state stock exchanges [9][10]. Sutheebanjard and Premchaiswadi [11] found that the Dow Jones index, Nikkei index, Hang Seng Index affect the Stock Exchange of Thailand.

The Dow Jones index is one of the top stocks in the United States and may affect the stock exchange price index in various countries, one of which is the IHSG index in period of 2013-2015. the result of this research is consistent with [12][13]. The other global stock price index is the Straits Times index which is the best stock price index in Southeast Asian countries owned by the state of Singapore, this index also affects on the stock price index of different countries, including IHSG Index. These results are consistent with the results of previous studies [14][15]. Similar research has also been done by Prayitno [16], which finds global share price index to influence the IHSG Index.

\section{Conclusion}

Based on the results of this study can be concluded that the Nasdaq index, Dow Jones index, Straits Times index has a relationship with the Composite Stock Price Index, the Nasdaq index, Dow Jones index, Straits Times index able to explain the effect on the Composite Stock Price Index. Partial test of three variables consisting of Nasdaq index, Dow Jones index, Straits Times index have a positive and significant effect to Composite Stock Price Index in Indonesia Stock Exchange.

\section{References}

[1] Sunariyah, Pengantar Pengetahuan Pasar Modal. Yogyakarta: UPP STIM YKPN, 2013.

[2] T. Eduardus, "Analisis Investasi dan Manajemen Portofolio," BPFE UGM, Yogyakarta, 2001.

[3] J. C. Van Horne and J. M. Machowicz, "Prinsip-prinsip Manajemen Keuangan, Edisi pertama penerjemah Dewi Fitri Asari dan Deno A,” Kwary, Salemba Empat, Buku Satu, Jakarta, 2005. 
[4] H. M. Jogiyanto, "Metodologi Penelitian Sistem Informasi," Yogyakarta Penerbit Andi, 2008.

[5] P. Anoraga and P. Pakarti, "Pengantar pasar modal," Jakarta: Rineka Cipta, 2001.

[6] T. Fardiansyah, "Kiat dan Strategi menjadi investor piawai," PT. Elex Media komputindo, Jakarta, 2002.

[7] A. F. Darrat and M. Zhong, "Permanent and transitory driving forces in the Asian-Pacific stock markets," Financ. Rev., vol. 37, no. 1, pp. 35-51, 2002.

[8] N. A. Achsani, "Mencermati Kejatuhan Indeks Dow Jones: Akankah Indeks BEJ Ikut Terseret," Univ. Potsdam. Potsdam, 2000.

[9] W. Wahyuni, S. Khairani, and C. D. Wenny, "Pengaruh Indeks Harga Saham Global Terhadap Pergerakan Indeks Harga Saham Gabungan (IHSG) di Bursa Efek Indonesia," Palembang, 2015.

[10] T. Sihombing, "Analisa Pengaruh Indeks Harga Saham Luar Negeri Terhadap Index Harga Saham Gabungan Indonesia: Suatu Bukti Empiris,” J. Ekon., vol. 7, no. 2, pp. 15-29, 2013.

[11] P. Sutheebanjard and W. Premchaiswadi, "Forecasting the Thailand stock market using evolution strategies," Asian Acad. Manag. J. Account. Financ., vol. 6, no. 2, 2010.

[12] T. S. J. Wijaya and S. Agustin, "Faktor-faktor yang mempengaruhi nilai IHSG yang terdaftar di Bursa Efek Indonesia," J. Ilmu dan Ris. Manaj., vol. 4, no. 6, 2015.

[13] R. Christa and W. A. Pratomo, "Analisis Pengaruh Indeks Harga Saham di Bursa Global terhadap Indeks Harga Saham Gabungan di BEI," J. Ekon. dan Keuang., vol. 1, no. 8, 2013.

[14] D. Kowanda, R. B. F. Pasaribu, and A. F. Shauti, "Pengaruh Indeks Bursa Saham Asing dan Makro Ekonomi Terhadap Indeks Harga Saham Gabungan di Bursa Efek Indonesia pada Tahun 2010-2014," J. Manaj. Indones., vol. 15, no. 3, pp. 225-234, 2015.

[15] N. Hidayah, "Pengaruh Indeks Bursa Asia Tenggara terhadap Indeks Harga Saham Gabungan (IHSG) di Bursa Efek Indonesia,” Universitas Gunadarma, 2013.

[16] B. B. Prayitno, "Pengaruh Indeks Bursa Saham Global, Harga Komoditas dan Nilai Tukar Mata Uang Asing Terhadap Indeks Harga Saham Gabungan,” Universitas Atma Jaya Yogyakarta, 2013. 